\title{
Sosialisasi Persepsi Remaja Tentang Body Image, Pola Aktivitas Fisik Dan Pengukuran Antropometri
}

\author{
Gina Puspita 1, Bambang Edi Susyanto², Suci Aprilia³ \\ 1Fakultas Kedokteran dan IImu Kesehatan UMY, Yogyakarta \\ 2 Fakultas Kedokteran dan IImu Kesehatan UMY, Yogyakarta \\ 3Alumni Fakultas Kedokteran dan Ilmu Kesehatan UMY, Yogyakarta \\ Alamat korespondensi FKIK-UMY JI Brawijaya, Geblagan, Tamantirto, Kec Kasihan, Bantul, DIY, Kode pos 55183 \\ Email: gina.puspita@umy.ac.id
}

\begin{abstract}
Abstrak
Latar Belakang: Status gizi remaja dipengaruhi oleh kebiasaan makan dan aktivitas fisik. Persepsi body image remaja diduga memengaruhi kebiasaan makan. Persepsi body image positif dan pola aktivitas fisik yang benar akan meningkatkan kualitas status gizi yang baik pada remaja. Kami melakukan pelatihan pengukuran antropometri, penilaian body image, dan aktivitas fisik pada remaja.

Tujuan: Melihat gambaran persepsi body image dan aktivitas fisik terhadap Index Masa Tubuh Remaja

Metode: Desain observasional deskriptif melibatkan 45 remaja dari SMA. Pelatihan pengukuran antropometri untuk mendapatkan hasil IMT kemudian dinilai menggunakan CDC 2000. Persepsi body image dinilai dengan skoring Figure Rating Scale (FRS).

Hasil: Didapatkan dari 45 remaja dengan hasil IMT persentil > 85 memiliki persepsi body image positif sebesar (67\%) dan sisanya (33\%) negatif. Remaja dengan hasil IMT persentil $>85$ sebagian besar melakukan aktivitas fisik (80\%).

Implikasi: Peserta dapat memahami cara pengukuran antropometri yang tepat. Pengenalan terhadap persepsi body image terhadap IMT peserta. Memahami pentingnya melakukan aktivitas fisik pada remaja yang tepat.

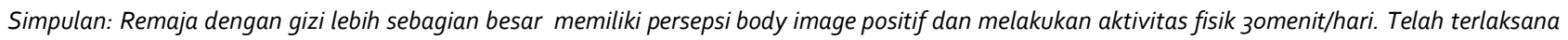
kegiatan pengabdian pengembangan SMA Muhammdiyah Sleman, dari tahap sosialisasi hingga terbentuknya persepsi yang baik mengenai body image dan aktivitas fisik pada remaja.

Kata kunci: antropometri, body image, aktivitas fisik, status gizi.
\end{abstract}

\section{Pendahuluan}

Obesitas selama masa anak-anak dan remaja merupakan masalah kesehatan dunia yang semakin meningkat prevalensinya. Pada beberapa penelitian menyebutkan angka kejadian obesitas tahun 2016 mencapai 40 juta anak dibawah usia 5 tahun dan lebih dari 330 juta pada usia 5-19 tahun.

Pada remaja yang mengalami obesitas selain komorbiditas berupa penyakit sistemik juga berdampak pada kondisi psikologis. Persepsi remaja mengenai bentuk tubuh (body image) ideal sangat memengaruhi tingkat kepercayaan diri dan kondisi emosional. Pada saat remaja terjadi perubahan pubertas dan perkembangan tubuh yang drastis. Remaja akan lebih memperhatikan tubuhnya. Penelitian Lo et al., menggunakan metode figure rating scale (FRS) untuk melakukan identifikasi anak dengan gizi kurus dan lebih di Cina. Cara ini dinilai mudah dan reliabel untuk menilai persepsi body image pada remaja. Pada skema pengabdian masyarakat kami juga mengadopsi menggunakan metode figure rating scale (FRS) untuk menilai persepi body image pada remaja.

Terapi pada anak remaja dengan obesitas cukup sulit dilakukan. Beberapa penelitian menunjukkan anak remaja dengan obesitas juga akan mengalami hal yang sama saat dewasa sehingga mereka dinilai gagal untuk menurunkan berat badan saat usia remaja. Selain dengan terapi diet makanan, adanya pola aktivitas yang benar pada anak dan remaja dengan obesitas dapat berpengaruh terhadap penggunaan energi. Peningkatan aktivitas pada anak gemuk dapat menurunkan nafsu makan dan meningkatkan laju metabolisme. Latihan aerobik teratur yang 
dikombinasikan dengan pengurangan energi akan menghasilkan penurunan berat badan yang lebih besar dibandingkan hanya dengan diet saja. Pada pengabdian masyarakat kali ini, tim juga akan melakukan penyuluhan mengenai diet dan aktivitas fisik yang sesuai untuk remaja obesitas agar target penurunan berat badan dapat tercapai dengan baik.

Tujuan kegiatan ini adalah untuk menggali masalah yang terjadi pada perubahan fisik saat remaja dan menilai persepsi body image pada masa remaja yang masih sangat dipengaruhi oleh faktor lingkungan. Selain itu, tim juga ingin memperbaiki pengetahuan para remaja dan guru mengenai pengukuran antropometri yang tepat pada fase remaja dengan menggunakan kurva CDC 2000 sesuai dengan usia dan jenis kelaminnya.

\section{Metode Pelaksanaan}

Metode pelaksanaan yang digunakan adalah: 1). Pemberian penyuluhan edukasi melalui video Youtube, 2). Membuat media ajar berupa booklet yang dibentuk file pdf kemudian dibagikan pada peserta, 3). Melakukan diskusi bersama dengan kelompok peserta melalui online dengan Zoom, dan 4). Pembagian kuesioner untuk mengetahui hasil penyampaian edukasi.

\section{Hasil dan Pembahasan \\ Kegiatan}

Kegiatan pengabdian masyarakat ini dilakukan selama pandemi COVID-19. Dikarenakan ada keterbatasan berupa lockdown dan meliburkan anak sekolah, sehingga kegiatan yang awalnya direncanakan berupa penyuluhan ke SMA diubah menjadi pemberian edukasi dengan metode pelatihan melalui video pembelajaran yang dibagikan via Youtube dan pembuatan booklet.

Pembelajaran edukasi via Youtube diberikan dengan materi yang berjudul "Deteksi Dini Obesitas dan Tatalaksana Aktivitas Fisik pada anak Obesitas." Untuk pembelajaran melalui booklet akan menjelaskan lebih lanjut mengenai Pelatihan Pengukuran Antropometri Pada Anak dengan Obesitas.

Pengetahuan dan persepsi terhadap body image dilakukan dengan penilaian secara kuesioner menggunakan google form.

Tabel 1. JADWAL KEGIATAN

\begin{tabular}{llll}
\hline NO & WAKTU & URAIAN & KETERANGAN \\
\hline 1 & $12-3-2020$ & Perizinan & Pertemuan dengan PDM Sleman \\
\hline 2 & $22-07-$ & Penyuluhan & Pembuatan video edukasi mengenai “Aktivitas Fisik Pada Anak Obesitas” \\
& 2020 & & Pembuatan video edukasi mengenai “Deteksi dini Obesitas melalui pengukuran \\
\hline 3 & $25 / 07 / 2020$ & Penyuluhan & Antropometri dan Faktor Risiko Obesitas” \\
& & & Pembuatan booklet mengenai Deteksi Dini Obesitas dengan Pengukuran \\
\hline 4 & $30 / 07 / 2020$ & Pembuatan Booklet & Antropometri dan Aktivitas Fisik pada remaja serta penilaian body image. \\
\hline 5 & & & Pembuatan Whatsapp Grup untuk pelatihan pada guru Muhammadiyah. \\
& & & \\
\hline 6 & $15 / 08 / 2020$ & Pelatihan Guru SMA Muhammdiyah & Pelatihan melalui Zoom untuk Pengukuran Antropometri yang benar \\
& & ke-2 & \\
\hline 7 & $16 / 08 / 2020$ & Pembagian Kuesioner & Pemberian Kuesioner mengenai penilaian body image pada remaja melalui \\
& & & google form. \\
\hline
\end{tabular}




\section{Pengetahuan Pengukuran Antropometri}

Pengetahuan akan pengukuran antropometri pada anak dan remaja belum banyak diketahui selama ini oleh guru. Sebelum kegiatan pelatihan kami menilai bahwa guru masih sangat awam dengan penggunaan growth chart pada anak dan remaja.

Setelah dilakukan pelatihan melalui video dan penjelasan langsung via Whatsapp dan Zoom banyak guru yang mulai memahami bahwa dalam pengukuran antropometri pada anak dan remaja. Selain itu, guru juga telah memahami bagaimana memasukkan hasil pengukuran berat badan dan panjang badan setelah diberikan beberapa contoh soal.

Luaran:

- Pembuatan video Youtube melalui link : Judul Video “Peran Orang Tua dan Guru dalam Deteksi Dini Obesitas Pada Anak" https://www.youtube.com/watch?v=g14fMsUBx_o

- Penjelasaan melalui presentasi via Zoom melalui link:

Join Zoom Meeting https://us02web.zoom.us/j/8516940327?pwd=eWM0bFpISTZyQ0J3dW1GWHN2dTNvUT 09

- Pembuatan Booklet

\section{Pengetahuan Aktivitas Fisik}

Pengetahuan akan aktivitas fisik yang benar dan tepat pada remaja belum banyak diketahui selama ini oleh guru. Sebelum kegiatan pelatihan kami menilai bahwa guru masih sangat awam dengan pelatihan aktivitas fisik mulai dari durasi dan pilihan jenis aktivitas fisiknya.

Hasil dari kuesioner didapatkan remaja obesitas sebagian besar (80\%) telah melakukan aktivitas fisik selama 30 menit/hari. Namun, frekuensi setiap minggu tidak menentu. Pada remaja dengan status gizi normal (65\%) juga sering melakukan aktivitas fisik harian selama 30 menit/hari.

Luaran:

- Penjelasaan melalui presentasi via Zoom melalui link:

Join Zoom Meeting https://us02web.zoom.us/j/8516940327?pwd=eWM0bFpISTZyQ0J3dW1GWHN2dTNvUT0 9

- Pembuatan Booklet

- Kuesioner tentang aktivitas fisik : https://forms.gle/cZjVQGkakL1BeFaL

\section{Penilaian Remaja mengenai Body Image}

Pada pengabdian ini, total peserta yang melakukan pengisian kuesioner mengenai persepsi remaja terhadap body image sebanyak 45 peserta. Pada pengabdian ini, kami melakukan penilaian persepsi body image dengan menggunakan metode Figure Rating Scale (FRS) Stunkard yang terdiri dari delapan anak remaja dengan status gizi pada gambar dari gizi 
kurang hingga lebih. Gambar nomor 1 sampai 3 memiliki status gizi kurang, gambar nomor 4 sampai 6 memiliki status gizi normal, dan gambar 7 sampai 8 memiliki status gizi lebih.
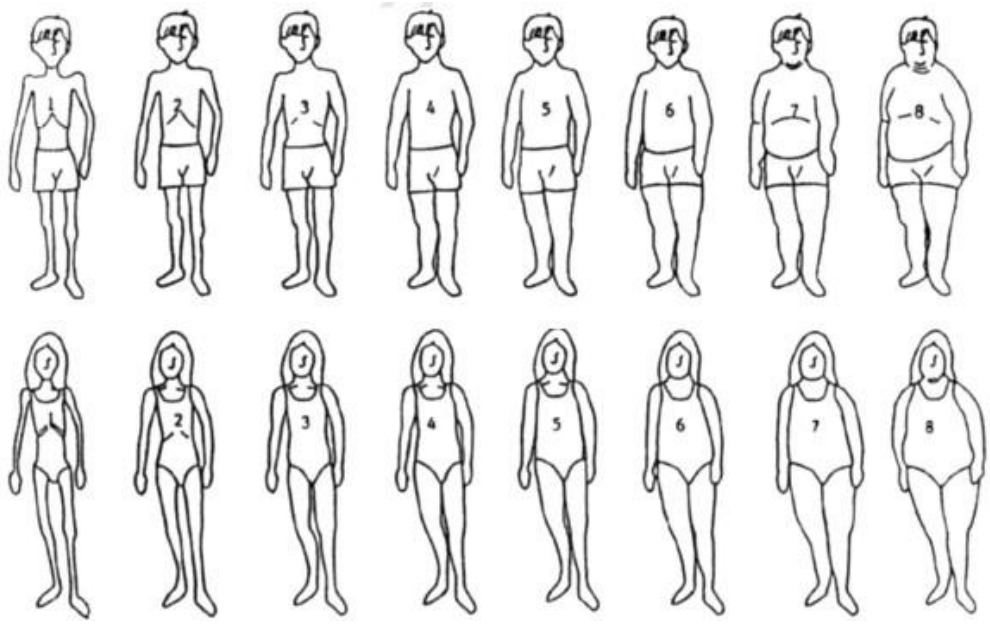

Gambar 1. Figure Rating Scale (FRS)

Jenis persepsi diukur dengan membandingkan status gizi aktual terhadap persepsi bentuk tubuh aktualnya. Apabila persepsi terhadap bentuk tubuh aktualnya berbeda dengan status gizi aktualnya, maka hal ini dapat dikatakan sebagai persepsi tubuh negatif. Sebaliknya, apabila persepsi terhadap bentuk tubuh aktualnya sama dengan status gizi aktualnya, maka hal ini dapat dikatakan sebagai persepsi tubuh positif.

Hasil pengabdian menunjukkan bahwa dari 45 peserta didapatkan 35 (76.\%) peserta memiliki persepsi tubuh yang positif dan 10 (21.7\%) peserta memiliki persepsi tubuh yang negatif. Persepsi bentuk tubuh ideal secara umum (77\%) adalah bentuk tubuh dengan status gizi normal. Remaja obesitas memiliki persepsi bentuk tubuh ideal (73\%) adalah status gizi normal, kemudian untuk status gizi kurang sebanyak (20\%), dan sisanya (6\%) pada status gizi obesitas. Pada remaja dengan gizi normal memiliki persepsi bentuk tubuh ideal sebagian besar $(82 \%)$ adalah status gizi normal dan sebanyak (18\%) status gizi kurang. Seluruh remaja kurus memiliki persepsi bentuk tubuh ideal (100\%) adalah status gizi normal. Tim juga menilai persepsi bentuk tubuh saat dewasa yang diinginkan secara umum (77\%) adalah gizi normal dan sekitar (22\%) memiliki persepsi gizi kurang.

Luaran:

- Kuesioner tentang Body Image:

\section{https://forms.gle/cZjVQGkakL1BeFaL8}

- Penjelasaan melalui presentasi via Zoom melalui link:

Join Zoom Meeting https://us02web.zoom.us/j/8516940327?pwd=eWM0bFpISTZyQ0J3dW1GWHN 2dTNvUT09 


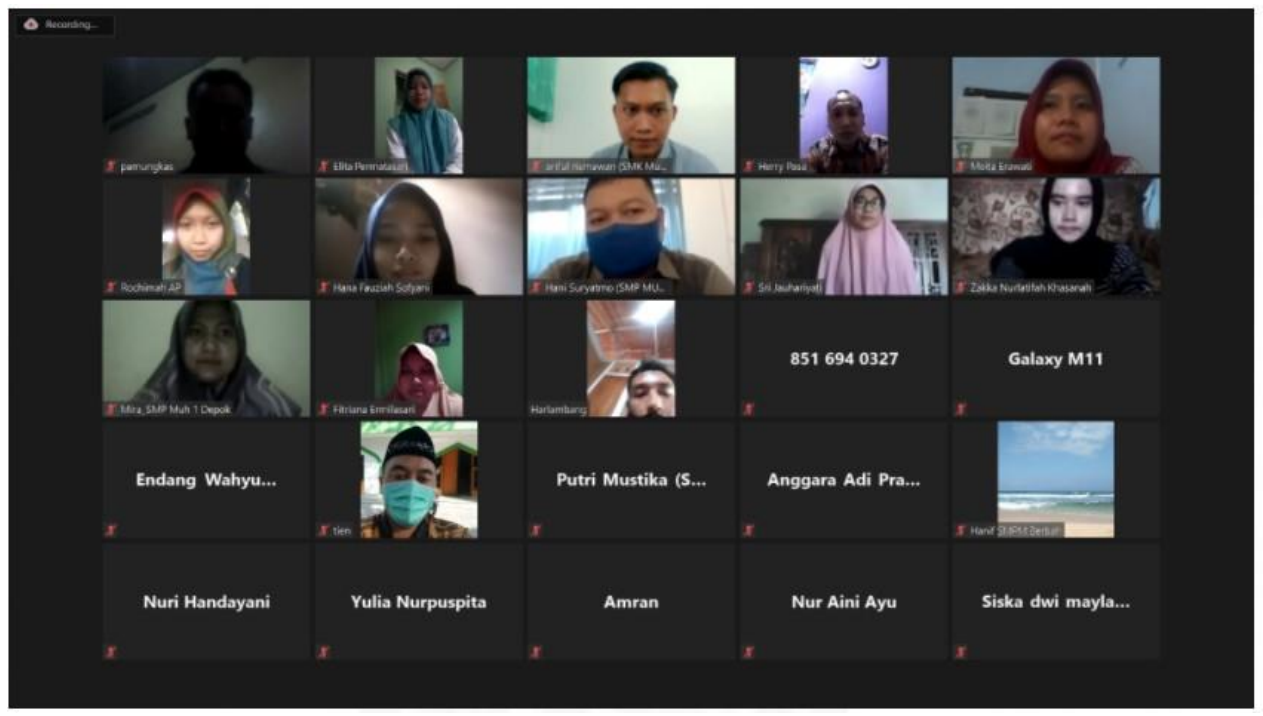

Gambar 2. Pelatihan via Zoom

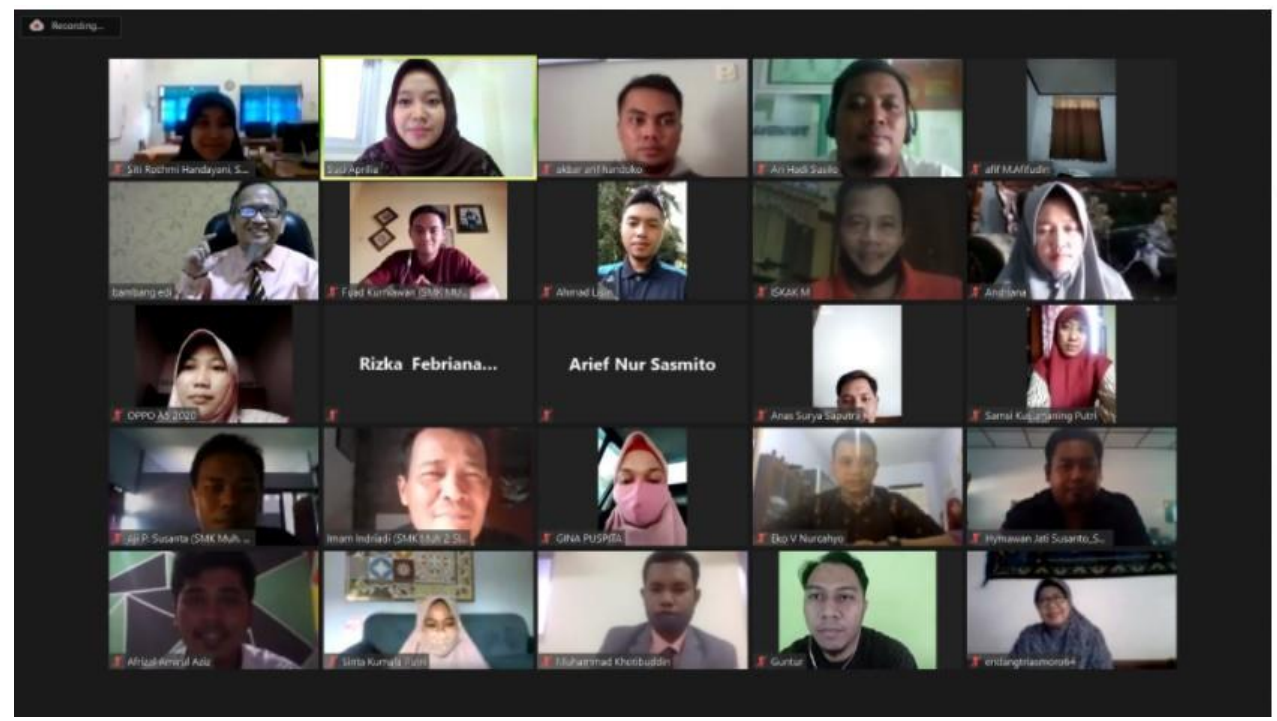

Gambar 3. Pelatihan via Zoom

\section{Simpulan}

Remaja dengan gizi lebih sebagian besar memiliki persepsi body image positif dan melakukan aktivitas fisik 30menit/hari. Telah terlaksana kegiatan pengabdian pengembangan di SMA Muhammdiyah Sleman, dari tahap sosialisasi hingga terbentuknya persepsi yang baik mengenai body image dan aktivitas fisik pada remaja. Harapannya kegiatan ini dapat dilanjutkan untuk dapat melakukan edukasi pada masyarakat khususnya remaja untuk meningkatkan produktivitas usia remaja. 


\section{Saran}

Kegiatan pengabdian masyarakat ini sebaiknya ditindaklanjuti dengan beberapa kegiatan misalnya berbagai pelatihan dan pendampingan untuk mengukur antropometri, pengukuruan jumlah asupan makanan, dan kegiatan aktivitas fisik yang secara rutin. Kesehatan remaja akan lebih terpantau dengan baik dan produktivitas remaja dapat tercapai dengan baik.

\section{Ucapan Terima kasih}

Terima kasih disampaikan kepada Fakultas Kedokteran Universitas Muhammadiyah Yogyakarta yang telah menyediakan dana kegiatan, Majelis Dikdasmen Sleman, SMA Muhammadiyah Sleman

\section{DAFTAR PUSTAKA}

Di Cesare M, Sorić M, Bovet P, Miranda JJ, Bhutta Z, Stevens GA, et al. The epidemiological burden of obesity in childhood: A worldwide epidemic requiring urgent action. BMC Med. 2019;17(1):1-20.

Ikatan Dokter Anak Indonesia. Diagnosis, Tata Laksana dan Pencegahan Obesitas pada Anak dan Remaja. Ikat Dr Anak Indones. 2014;1.

Abbasi A, Juszczyk D, van Jaarsveld CHM, Gulliford MC. Body Mass Index and Incident Type 1 and Type 2 Diabetes in Children and Young Adults: A Retrospective Cohort Study. J Endocr Soc. 2017;1(5):524-37.

Agrawal N, Kumar Agrawal M, Kumari T, Kumar S. Correlation between Body Mass Index and Blood Glucose Levels in Jharkhand Population. Int J Contemp Med Res ISSN [Internet]. 2017;4(8):1633. Available from: www.ijcmr.com.

Lestari WD. Kebiasaan Makan Dan Persepsi Body Image Pada Siswa Smp Berstatus Gizi Lebih Dan Normal Pernyataan Mengenai Skripsi Dan Sumber Informasi Serta Pelimpahan Hak Cipta *. 2014;

Lynch E, Liu K, Wei GS, Spring B, Kiefe C, Greenland P. The relation between body size perception and change in body mass index over 13 years. Am J Epidemiol. 2009;169(7):85766.

Lo WS, Ho SY, Mak KK, Lam TH. The Use of Stunkard's Figure Rating Scale to Identify Underweight and Overweight in Chinese Adolescents. PLoS One. 2012;7(11). 